\title{
A comparative analysis of the suitability of different peripheral blood samples for reverse transcriptase polymerase chain reaction
}

\author{
Análise comparativa da adequação de diferentes amostras de sangue periférico em ensaios de \\ reação em cadeia da polimerase via transcriptase reversa
}

\author{
Adriene Siqueira de Melo ${ }^{l}$ \\ Virginia Maria Barros de Lorena \\ Suellen Carvalho de Moura Braz ${ }^{I}$ \\ Yara de Miranda Gomes ${ }^{1}$
}

\begin{abstract}
Venipuncture is one of the easiest clinical procedures to obtain viable blood samples to evaluate gene expression using $m R N A$ analysis. However, the use of this sample type in reverse transcriptase polymerase chain reaction tests (RT-PCR) without prior treatment is controversial. We therefore propose to compare the suitability of different peripheral blood samples (whole blood without treatment, whole blood with hemolysis, peripheral blood mononuclear cells and frozen whole blood) for RT-PCR analysis. The results showed that, despite the blood sample being peripheral, it is possible to extract a fair amount of RNA and perform target gene amplification. Thus, peripheral blood without prior treatment could be used to investigate the gene expression using Real Time PCR.

Keywords: Blood specimen collection/methods; Gene expression; RNA, messenger/ blood; Transcription, genetic/immunology; Reverse transcriptase polymerase chain reaction/methods; Spectrophotometers
\end{abstract}

\section{Introduction}

Evaluation of the gene expression by reverse transcriptase polymerase chain reaction (RT-PCR) tests has been widely used in scientific research. However, the kind of samples and the reagents used in the protocols of RNA extraction may contain substances which inhibit the reaction.

Collecting blood through venipuncture is a simple clinical procedure to obtain a viable blood sample for the evaluation of gene expression by mRNA detection. Nevertheless, some studies claim that such samples contain PCR inhibitors, and that it is therefore first necessary to perform a procedure to separate the peripheral blood mononuclear cells (PBMC). ${ }^{(1)}$ Another option would be to conduct blood hemolysis prior to RNA extraction. ${ }^{(2)}$ Blood also contains high levels of RNases, which are the primary cause of RNA sample degradation. This degradation occurs if the quality of the employed procedures is not controlled rigorously..$^{(3)}$

In view of the doubts that have been cast on the use of whole blood without previous treatment for these molecular tests, the aim of the present report is to compare the suitability of different peripheral blood samples for RTPCR analysis.

\section{Methods}

Ten volunteers were selected from the Immunoparasitology Laboratory of the Immunology Department at the Aggeu Magalhães Research Center/Fiocruz (CPqAM/ Fiocruz) and from the Hospital Universitário de Pernambuco (UPE), both situated in the city of Recife, State of Pernambuco, Brazil. The study was approved by the Research

\footnotetext{
${ }^{I}$ Immunoparasitology Laboratory of the Immunology Department at the Aggeu Magalhães Research Center/Fiocruz (CPqAM/Fiocruz) and from the Hospital Universitário Oswaldo Cruz, Universidade de Pernambuco - UPE - Recife (PE), Brazil.

Conflict of interest: none

Correspondence: Yara de Miranda Gomes

Departamento de Imunologia, Centro de Pesquisas Aggeu Magalhães/Fiocruz

Av. Moraes Rego s/n, Cidade Universitária

50670-420 - Recife (PE), Brasil

Tel.: (55 81) 2101-2559; Fax: (55 81) 2101-2674

E-mail:yara@cpqam.fiocruz.br
} 
Ethics Committee of CPqAM/Fiocruz ( $\mathrm{N}^{\circ}$. 032009). The participants were informed about the nature of the research, its objectives and methods and all participants signed written consent forms.

Peripheral blood was collected using the vacuum system (Vacutainer ${ }^{\circledR}$ ) in $10 \mathrm{ml}$ tubes containing heparin. In order to evaluate the viability of stored frozen whole blood, the samples of individuals from the Huoc-Upe were, after culturing, stored in Trizol at $-20^{\circ} \mathrm{C}$ for 6 months, whereas the other samples were immediately processed for PBMC and whole blood cultures with or without hemolysis.

The cells were cultured as follows: i) For whole blood, heparinized blood was diluted 1:2 in an RPMI 1640 medium (Sigma) SBF $(10 \%)$ and incubated at $37^{\circ} \mathrm{C} / 5 \% \mathrm{CO}_{2}$ for 24 hours. For samples processed immediately, cultures were performed in duplicate for subsequent hemolysis in one of the tubes. ii) In the case of PBMC, separation was performed in accordance with the protocol developed by Lorena et al. ${ }^{(4)} \mathrm{A} 10^{6}$ cell $/ \mathrm{ml}$ concentration was placed in culture tubes in a $1 \mathrm{ml}$ final volume of medium. The tubes were incubated in a $5 \% \mathrm{CO}_{2}$ environment and cultured at $37^{\circ} \mathrm{C}$ for 24 hours.

Hemolysis was performed by adding $8 \mathrm{ml}$ of lysing solution $(2.85 \%$ sodium citrate, $30 \%$ diethylene glycol, $54 \%$ of $37 \%$ formaldehyde, $0.04 \%$ of USP 100,000 heparin) to culture tubes previously set aside for this purpose. The tubes were incubated for 8 minutes in the dark until the solution was translucent. After this period, filtered PBS was added. Then, the solution was centrifuged at $460 \mathrm{x}$ g for 10 minutes and the supernatant removed with a vacuum pump.

Total RNA isolation was performed using the Trizol reagent (Invitrogen ${ }^{\circledR}$ ) according to the manufacturer's instructions. After extraction, samples were re-suspended in Rnase-Free Water (Invitrogen ${ }^{\circledR}$, Carslbad CA). Quantification was carried out using a spectrophotometer (Pharmacia Biotech) following the manufacturer's instructions. For the subsequent amplification tests, the sample group (whole blood without treatment, whole blood with hemolysis, PBMC and frozen whole blood) which showed the highest ratio was chosen. The normalization of concentrations was carried out at a $30 \mu \mathrm{g} / \mathrm{ml}$ final concentration. The integrity of the extracted RNA was evaluated by $1.2 \%$ agarose denaturing electrophoresis with visualization using ethidium bromide stain. The gel was analyzed in a photo documentation system (Gel Logic 100, Imaging System).

For the reverse transcription reaction, tubes with a $13 \mu \mathrm{L}$ mixture containing $4 \mu \mathrm{l}(500 \mathrm{ng})$ total RNA, $1 \mu 1$ Oligo dT primer $(50 \mu \mathrm{M}), 1 \mu 1 \mathrm{dNTP}(10 \mathrm{mM})$, and $7 \mu 1$ Rnase-free water, were placed in a dry bath for $5 \mathrm{~min}$ at $65^{\circ} \mathrm{C}$ followed by $1 \mathrm{~min}$ in an ice bath. As a second step, $7 \mu 1$ of sample mix was added to each tube (5X RT buffer [ $250 \mathrm{mM}$ Tris-HCl, $\mathrm{pH}$ $8.3,375 \mathrm{mM} \mathrm{KCl}, 15 \mathrm{mM} \mathrm{MgCl}_{2}$ ], DTT [0.1 M]; RNase inhibitor [40 U/ $\mu 1]$; MMLV reverse transcriptase enzyme [50 U/ $\mu \mathrm{l}]$ ) (Applied Biosystems ${ }^{\circledR}$ ) to a final volume of $20 \mu$ l per reaction.
Samples were incubated at $50^{\circ} \mathrm{C}$ for 1 hour followed by $70^{\circ} \mathrm{C}$ for $15 \mathrm{~min}$, whereupon they were re-suspended in $80 \mu \mathrm{l}$ Rnase-free water. A negative control without sample and a reaction control without enzyme were also used. In order to compare the "in-house" protocol with a commercial kit, the samples were submitted to reverse transcription using the SuperScript III First-Strand Synthesis System kit for RTPCR (Invitrogen ${ }^{\circledR}$ ) following the manufacturer's instructions.

The samples were evaluated using conventional PCR with the human $\beta$-globin gene as the target. A $48 \mu 1$ sample mix was thus used ([1.5 mM TBMG], [20 pmol] forward primer and [20 pmol] reverse; [200 mM] dNTP; [5U/ $\mu \mathrm{l}]$ Recombinant Taq DNA polymerase; miliq water) and $2 \mu 1$ of each cDNA sample. Amplification was performed in a Mastercycler

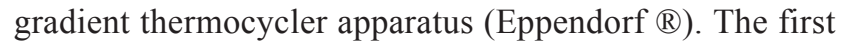
stage transcript was performed at $94^{\circ} \mathrm{C}$ for 30 seconds, followed by heating to $55^{\circ} \mathrm{C}$ for 30 seconds, one denaturation cycle at $55^{\circ} \mathrm{C}$ for 60 seconds, annealing at $72^{\circ} \mathrm{C}$ for 30 seconds, extension at $72^{\circ} \mathrm{C}$ for 90 seconds followed by 35 consecutive cycles of denaturation, annealing and extension at $94^{\circ} \mathrm{C}$ for 30 seconds, $55^{\circ} \mathrm{C}$ for 30 seconds, $72^{\circ} \mathrm{C}$ for 30 seconds respectively, and with a hold temperature of $20^{\circ} \mathrm{C}$. To observe the specific band of the $\beta$-globin gene, $2 \%$ agarose gel electrophoresis was performed with visualization by ethidium bromide stain. Gel analysis was carried out using a photo documentation system (Gel Logic 100 Imaging System).

\section{Results}

Spectrophotometer RNA analysis showed that it was possible to obtain a good degree of nucleic acid purity (ratio between 1.8 and 2.0) in adequate amounts (concentrations between $30 \mu \mathrm{g} / \mathrm{ml}$ and $304 \mu \mathrm{g} / \mathrm{ml}$ ) for all the sample types (whole blood without treatment, whole blood with hemolysis, PBMC and frozen whole blood).

With regards to the quality of RNA, the electrophoretic profiles indicated that the RNA was intact without any degradation in all samples (Figure 1), which suggests that the RNA was not subjected to the action of RNase in the samples and/or in the materials used.

Analysis of the adequacy of samples for RT-PCR using ß-globin gene amplification showed the 110pb target for all sample types and protocols employed in reverse transcription (Figure 2).

\section{Discussion}

Historically, the assessment of the integrity of RNA has been performed using agarose gel with ethidium bromide stain. Typically, these gels show two ribosomal RNA (rRNA) bands of $28 \mathrm{~S}$ and $18 \mathrm{~S}$. In this kind of analysis, the quality of the RNA is considered good when the $28 \mathrm{~S} / 18 \mathrm{~S}$ ratio is equal 


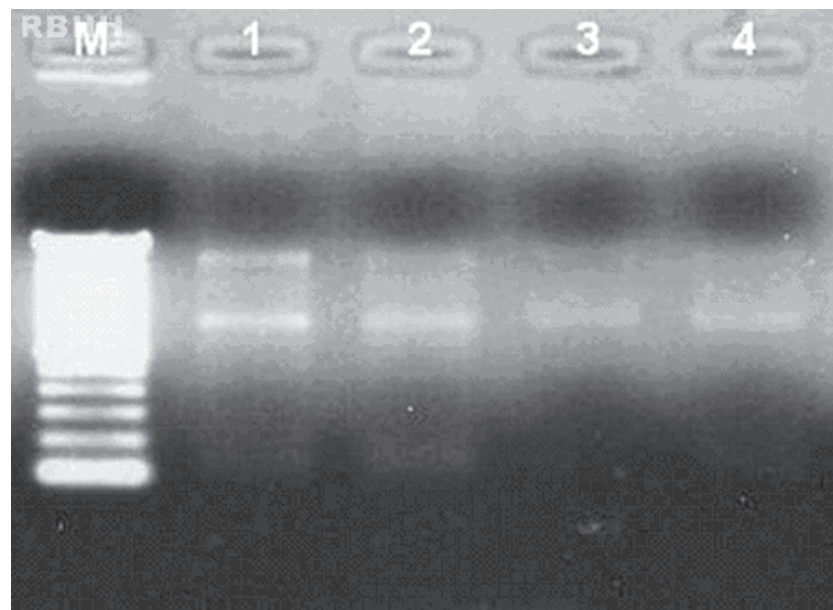

Figure 1. Relationship between $28 \mathrm{~S} / 18 \mathrm{~S}$ ribosomal RNA bands using $1.2 \%$ denaturing agarose gel. Electrophoretic profile descriptions: $(\mathrm{M})$ : Molecular Weight - (1): whole blood with hemolysis (2): whole blood without treatment (3): PBMC (4): whole blood kept frozen for 6 months.



Figure 2. $2 \%$ Agarose gel showing the amplified product of $110 \mathrm{pb}$ of $\beta$-globin gene A) Reverse transcription performed using a Kit (Invitrogen). B) Reverse transcription performed using an "in house" protocol. Electrophoretic profile descriptions: (M): Molecular Weight, (1): whole blood with hemolysis (2): whole blood without treatment (3): PBMC (4):whole blood kept frozen for 6 months (5): negative control: without sample (6): reaction control: without enzyme

to or greater than $2 .^{(5)}$ However, this interpretation appears to be subjective and difficult to reproduce, since this ratio is rarely found in literature, especially in cases of RNA derived from clinical samples, where the relationship between the electrophoretic pattern found for the rRNA and the integrity of mRNA has not been fully clarified. ${ }^{(6)}$ Therefore, in the absence of more sophisticated and accurate methods to establish the integrity of RNA, such as the 2100 bioanalyzer system for correct discrimination of DNA, RNA and protein, the electrophoretic profile evaluation should be performed to determine the banding pattern and the $28 \mathrm{~S} / 18 \mathrm{~S}$ ratio for each experiment. ${ }^{(7)}$ As found in our results, it is acceptable that even with a low ribosomal RNA ratio, the RNA is of good quality, especially if no degradation products are observed in the electrophoresis. ${ }^{(8)}$
Most traditional methods of RNA extraction, such as extraction by phenol chloroform or the use of Trizol, are known to potentially act as PCR inhibitors, which might increase the margin of error of the reaction..$^{(9)}$ In the present study, RNA extraction using the Trizol reagent was satisfactory to produce RNA in an appropriate quantity and of an appropriate integrity for further analysis. However, the variation in the RNA concentration observed in this study is certainly not related to the extraction method, because another study which compared three different methods to extract RNA from resins found that similar results were obtained, regardless of the method used. ${ }^{(10)}$

Furthermore, a study conducted by some authors ${ }^{(11)}$, which compared different protocols to extract RNA from paraffin-embedded samples, found that the cost-benefit remained constant for all of the principal methods available. This means that these traditional methods are cheaper than commercially available kits which employ more expensive advanced technology. This result was also reported by another authors, ${ }^{(12)}$ who stated that the quantity and quality are factors which are independent of the RNA extraction method.

Regarding the implementation of RT-PCR by B-globin gene amplification, our results show that when the extraction and purification of RNA are carried out in an appropriate manner, the choice of sample type and protocol depend only on costeffectiveness. In the case of the samples frozen for six months, the banding pattern was more subtle than the others. This indicates increased degradation of RNA in samples that are kept frozen for long periods of time.

As for the use of peripheral blood samples in studies to evaluate gene expression using PCR, some authors rule out the use of this kind of sample without prior treatment due to the high levels of RNase and PCR inhibitors, such as heme, immunoglobulin $G$ and lactoferrin. ${ }^{(13,14)}$ Additionally, blood samples collected using the anticoagulant heparin present an additional problem, because this drug also appears to be a strong inhibitor of PCR. ${ }^{(15)}$

Unlike the aforementioned studies, this report observed target amplification irrespective of the sample type, the presence of the anticoagulant heparin or the type of protocol used for RNA extraction or reverse transcription. In view of this, whole blood without prior treatment would appear to be a viable sample for this purpose. This is of great importance because even a few minutes after blood sample collection, the gene expression profile of cells changes significantly as a result of transcription induction and transcript degradation, in such a way that it is almost certain that purification processes, such as PBMC separation, introduce further changes in gene expression. ${ }^{(2)}$ 


\section{Conclusion}

The results presented in this report demonstrate that, irrespective of the sample type used, it was possible to extract RNA of an acceptable quality and in an acceptable quantity for RT-PCR testing and subsequent amplification of target genes. Peripheral blood without prior treatment is more practical for laboratory testing and could be used in tests that quantitatively assess gene expression, such as Real Time PCR.

\section{Resumo}

A punção venosa representa um dos procedimentos clínicos mais simples na obtenção de amostras de sangue periférico e avaliação da expressão gênica através da análise do RNA mensageiro. Contudo, a utilização desta amostra, sem um tratamento prévio, em ensaios de Transcrição Reversa (RT-PCR) é controverso. Desta forma, propomos comparar a adequação de diferentes amostras de sangue periférico (sangue total sem tratamento, sangue total após hemólise, células mononucleares do sangue periférico e sangue total congelado) em ensaios de Transcrição Reversa Os resultados mostraram que independente da amostra de sangue periférico é possivel extrair RNA em quantidade adequada e realizar a amplificação do gene alvo. Desta forma, o sangue periférico sem tratamento prévio pode ser utilizado em abordagens que envolvam a avaliação da expressão gênica por reação em cadeia da polimerase (PCR) em tempo real.

Descritores: Coleta de amostras sanguíneas/métodos; Expressão gênica; RNA mensageiro/sangue; Transcrição genética/imunologia; Reação em cadeia da polimerase da transcriptase inversa/métodos; Espectrofotômetros

\section{Acknowledgments}

We would like to thank the team of Dr. Milton Ozorio Moraes (Leprosy Laboratory - IOC/Fiocruz) for scientific support. We are also grateful to Ana Karine Soares and Andrea Moraes for technical assistance.

Financial support: This report received support from Conselho Nacional de Desenvolvimento Cientifico e Tecnológico (CNPq) and Coordenação de Aperfeiçoamento de Pessoal de Nivel Superior (Capes).Y.M. Gomes is in receipt of a CNPq (N $\left.{ }^{\circ} 306427\right)$ 2006-0) research fellowship. VMB Lorena received a CNPq PhD scholarship for the duration of the study. AS Melo and SCM Braz are in receipt of a CAPES (06407432421) and CNPq (N 133106) 2009-8) MSc scholarship, respectively.

\section{References}

1. Pilz D, Alfieri AF, Alfieri AA. Comparação de diferentes protocolos para a detecção do vírus da diarréia viral bovina por RT-PCR em grupos de sangue total e de soro sangǘneo, artificialmente contaminados. Semina: Ciências Agrárias. 2005;26(2):219-28.

2. Asare AL, Kolchinsky SA, Gao Z, Wang R, Raddassi K, Bourcier K, et al. Differential gene expression profiles are dependent upon method of peripheral blood collection and RNA isolation. BMC Genomics. 2008;9:474.

3. Fleige S, Pfaffi MW. RNA integrity and the effect on the realtime qRT-PCR performance. Mol Aspects Med. 2006;27(23):126-39.

4. Lorena VMB, Verçosa AF, Machado RC, Moitinho-Silva L, Cavalcanti MGA, Silva ED, et al. Cellular immune response from chagasic patients to CRA or FRA recombinant antigens of Trypanosoma cruzi. J Clin Lab Anal. 2008;22(2):91-8.

5. Sambrook J, Russel DW. Molecular cloning: a laboratory manual. CSH Laboratory Press. New York: Cold Spring Harbour; 2001

6. Monstein HJ, Nylander AG, Chen D. RNA extraction from gastrointestinal tract and pâncreas by a modified Chomczynski and Sacchi method. Biotechniques. 1995;19(3):340-4.

7. Marx V. RNA quality: defininf the good, the bad, the ugly [Internet].Genomics \& Proteomics. [about 8 p.] [cited 2010 Jun 21]. Available from: http://www.dnaarrays.org/P_GenProMag.pdf

8. Imbeaud S, Graudens E, Boulanger V, Barlet X, Zaborski P, Eveno $\mathrm{E}$, et al. Toward standardization of RNA quality assessment using user-independent classifiers of microcapillary electrophoresis traces. Nucleic Acids Res. 2005;33(6):e56.

9. Barea JA, Pardini MIM, Gushiken T. Extração de DNA de materiais de arquivo e fontes escassas para utilização em reação de polimerização em cadeia (PCR). Rev Bras Hematol Hemoter. 2004;26(4):274-81.

10. Ribeiro-Silva A, Garcia SB. Estudo comparativo de três diferentes procedimentos para extração de RNA a partir de amostras fixadas em formalina e embebidas em parafina. J Bras Patol Med Lab. 2008;44(2):123-30

11. Vincek V, Nassiri M, Block N, Welsh CF, Nadji M, Morales AR. Methodology for preservation of high molecular-weight RNA in paraffin-embedded tissue: application for laser-capture microdissection. Diagn Mol Pathol. 2005;14(3):127-33.

12. Chung JY, Braunschweig T, Hewitt SM. Optimization of recovery of RNA from formalin-fixed, paraffin-embedded tissue. Diagn Mol Pathol. 2006;15(4):229-36.

13. Al-Soud WA, Radstrom P. Purification and characterization PCRinhibitory components in blood cells. J Clin Microbiol. 2001;39 (2):485-93

14. Perch-Nielsen IR, Bang DD, Poulsen CR, El-Ali J, Wolff A. Removal of PCR inhibitors using dielectrophoresis as a selective filter in a microsystem. Lab Chip. 2003;3(3):212-6.

15. Glaum MC, Wang Y, Raible DG, Schulman ES. Degranulation influences heparin-associated inhibition of RT-PCR in human lung mast cells. Clin Exp Allergy. 2008;31(10):1631-5.

Received: 15/5/2010

Accepted: 7/7/2010 